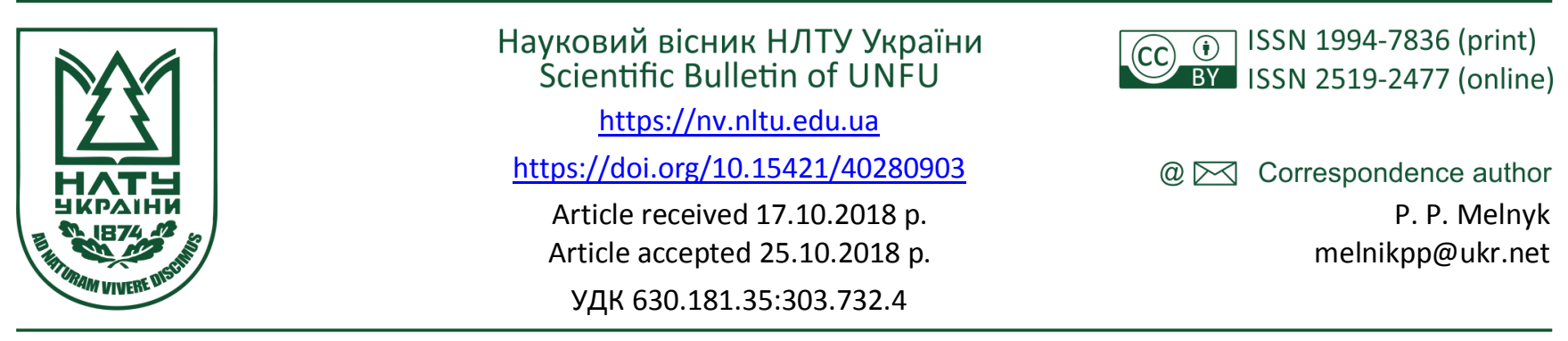

П. П. Мельник, Н. В. Курбацька

Інститут агроекології і природокористування, НААН України, м. Київ, Україна

\title{
ЕКОЛОГО-ЕКОНОМІЧНІ МЕХАНІЗМИ УПРАВЛІННЯ ПРИРОДОКОРИСТУВАННЯМ В АГРОЕКОСИСТЕМАХ
}

Розглянуто важливу роль розроблених нових і використання діючих еколого-економічних механізмів управління в галузях агроекосистем, що сприяють раціональному використанню і відтворенню природних ресурсів. Проведено аналіз діючих механізмів, які становлять основу гармонійного поєднання принципів для природокористування в агроекосистемах. Обгрунтовано особливості дії космічного механізму, який є сукупністю станів і процесів природного походження, та за своєю масштабністю дії він здатний не тільки спричиняти розвитку негативних наслідків, що призводять до непередбачених утрат, але й забезпечувати одержання в окремих фазах циклу сонячної активності економічного ефекту від виробництва сільськогосподарської культури. Наведено основні принципи еколого-економічних механізмів управління використанням та охороною земель. Акцентовано увагу на моніторингу як складу економічного механізму, який всебічно аналізує на макро- і мікрорівні регіонів виробничу сферу за найвагомішими показниками еколого-економічного спрямування. На основі проведених досліджень зроблено висновок, що для забезпечення ефективного ведення сільськогосподарського виробництва структура системи еколого-економічного управління має бути доповнена космічним механізмом, який сприяє вирішенню еколого-економічних і соціальних проблем у суспільному виробництві.

Ключові слова: агроекосистеми; використання; еколого-економічні механізми; принципи; природокористування; управління.

Вступ. Зростаюча інтенсивність експлуатації природних ресурсів, відсутність коштів у значної частини суб'єктів господарювання не сприяють вживанню заходів щодо зменшення впливу на НПС (навколишнє природне середовище) й ускладнюють формування концептуальних основ збалансованого розвитку. Це потребує розроблення оптимальної еколого-економічної стратегії подальшого розвитку складових системи управління природокористуванням у галузях агроекосистем.

Незважаючи на посилену увагу до забезпечення ефективності використання природних ресурсів у суспільному виробництві, їхній стан залишається незадовільним. Така ситуація спонукала систему еколого-економічного управління враховувати специфічні особливості, коли механізм гармонізації екологічної компоненти поєднується зі стратегією соціально-економічного розвитку агроекосистем для досягнення сталого розвитку та збереження цілісності еколого-економічних і соціальних компонентів у суспільному виробництві (Golovina \& Melnyk, 2014; Melnyk, 2016).

Важливу роль у вирішенні цієї проблеми відіграють розроблення нових і використання діючих еколого-економічних механізмів управління в галузях агроекосистем, що сприяють раціональному використанню і відтворенню природних ресурсів, охороні НПС та забезпеченню виробництва екологічно безпечної продукції.

Система механізмів у природокористуванні агроекосистем характеризується складністю і масштабністю вирішення проблем. Вони мають велике значення під час збалансованості еколого-економічних і соціальних компонент у сільськогосподарському виробництві.

Стратегічною метою механізму управління в галузях агроекосистем $є$ досягнення розвитку на основі формування та постійного відтворення економічних передумов природокористування і забезпечення ресурсозбереження суб'єктами господарювання всіх рівнів системи завдяки доведенню їх до такого стану, який сприятиме найвигіднішому вкладенню коштів, порівняно 3 альтернативними варіантами (Khvesyk, 2013).

На особливу увагу заслуговує визначення екологоекономічного механізму управління природокористуванням, який зумовлює багаторівневу систему взаємозв'язків екологічних та економічних явищ у процесі використання i реалізації ресурсозберігаючих заходів суб'єктами господарювання різних форм власності, забезпечуючи при цьому їхній сталий екологічно збалансований розвиток на самовідтворюваній основі, що $є$ стратегічним напрямом його розвитку (Khvesyk, 2013; Golovina, Tereshshenko \& Melnyk, 2015).

Визначення мети еколого-економічного механізму системи управління у природокористуванні агроекосистем дає змогу сформулювати важливі завдання багато-

\section{Інформація про авторів:}

Мельник Петро Павлович, д-р екон. наук, ст. наук. співробітник, завідувач лабораторією екологічного менеджменту. Email: melnikpp@ukr.net

Курбацька Наталія Вікторівна, аспірант, лабораторія екологічного менеджменту. Email: qoq404@gmail.com Цитування за ДстУ: Мельник П. П., Курбацька Н. В. Еколого-економічні механізми управління природокористуванням в агроекосистемах. Науковий вісник НлтУ України. Серія Економічна. 2018, т. 28, № 9. С. 21-26

Citation APA: Melnyk, P. P., \& Kurbatska, N. V. (2018). Ecological and economic mechanisms of natural resource management in agroecosystems. Scientific Bulletin of UNFU, 28(9), 21-26. https://doi.org/10.15421/40280903 
рівневої економічної системи. Це стосується зокрема вдосконалення системи управління у межах організаційно-правового поля; приділення уваги механізму функціонування і розвитку економіки вирощування сільськогосподарських культур; вирішення складних соціально-економічних проблем; визначення динамічного стану НПС. 3 методичного погляду, еколого-економічний механізм сприяє реалізації стратегічних напрямів господарювання, спрямованих на збереження та ефективне використання природно-ресурсного потенціалу як на рівні окремого суб'єкта господарювання, так і на рівні регіонального утворення. Отже, здійснюється ефективне природокористування, що запобігає виникненню негативних процесів та своєчасному вирішенню екологічних проблем в агроекосистемах.

Одним із важливих завдань у майбутньому основних форм еколого-економічних механізмів у процесі використання та охорони природних ресурсів, особливо земель сільськогосподарського призначення, $є$ збереження стійкості грунтів, що забезпечується механізмами як під час впливу екзогенних чинників, так і після припинення їхньої дії. Зокрема, у період впливу абіотичних чи антропогенних чинників, грунт для збереження своїх функцій виявляє такі механізми (Furdychko, 2014):

- стійкість як здатність горизонтів та деяких компонентів грунту зберігати склад і властивості під час хімічного й біохімічного впливу;

- міцність як здатність грунту та окремих його компонентів протидіяти зовнішньому впливу, не деформуючись до крайньої межі - руйнування;

- адаптація як здатність до збереження структури й особливості функціонування ценозу грунтових організмів унаслідок збурення його стану;

- інертність деяких компонентів грунту як здатність не взаємодіяти з екзогенними хімічними реагентами;

- буферність як здатність грунту підтримувати відносну стійкість окремих характеристик (pH, Eh) за невеликих змін його складу;

- пригнічення впливу фізичним опором, хімічною інактивацією, біологічним знищенням екзогенних речовин та організмів;

- інерційність реагування після впливу деяких чинників, що полягає у стримуванні різких, стрибкоподібних змін і забезпеченні повільних на початкових стадіях змін властивостей грунту під екзогенною дією;

- квазістаціонарний режим функціонування грунту, який забезпечує підтримання й оновлення внутрішнього складу, будови та особливостей зв'язків між компонентами в умовах зміни зовнішніх факторів грунтоутворення (насамперед унаслідок флуктуації кліматичного і біологічного чинників);

- збереження грунтом свого просторового розміщення;

- надійність функціонування грунту в складі геосистеми як його здатність виконувати вхідні, внутрішні й вихідні функції, зберігаючи у часі параметри, що забезпечують підтримання стану і функціонування інших компонентів геосистеми.

Аналіз діючих механізмів у системі еколого-економічного управління свідчить про те, що основу його становлять специфічні гармонійно поєднані принципи, дотримання яких $\epsilon$ необхідною передумовою підвищення ефективності функціонування галузей в агроекосистемі. Вони впливають на використання, відтворення, збереження природних ресурсів та охорону НПС.

Основними принципами еколого-економічних механізмів управління використанням та охороною земель є:
- збереження природних корисних властивостей грунту і запобігання втратам його продуктивності у просторово-часовому вимірі;

- завчасне передбачення і запобігання виникненню негативних наслідків господарської діяльності в агроекосистемах (деградація, забруднення НПС) та їх ліквідація;

- максимальне обмеження діяльності небезпечних суб'єктів господарювання, що погіршує природне екологічне функціонування НПС і знижує родючість грунтів в агроекосистемax;

- ефективне використання і відтворення природних ресурсів (родючість грунту, водойми, річки, ліси), яким сприяють природні чинники НПС;

- наукова обгрунтованість і забезпечення бездефіцитного балансу корисних властивостей грунту;

- цілеспрямоване й невиснажливе використання земельних ресурсів;

- сприяння природному відтворенню грунтів в агроекосистемax;

- пріоритет екологічних інтересів у землекористуванні над економічними;

- відшкодування втрат, заподіяних земельним ресурсам i НПС, заподіяних державою або суб'єктами господарювання різної форми власності;

- збалансоване землекористування;

- системний підхід до вирішення проблем у землекористуванні.

Важлива складова забезпечення ефективного природокористування в агроекосистемах - це врахування механізму дії фаз циклу сонячної активності. Грунтуючись на представленні цього механізму як сукупності станів і процесів природного походження, за своїм характером дії він здатний не тільки спричиняти негативні наслідки, що призводять до непередбачених утрат (заподіяння різного рівня збитків, утрата вигоди), або ставатися в майбутньому, але й забезпечувати одержання прибутку в окремих фазах циклу сонячної активності. Ми вважаємо, що цей механізм у сільському господарстві має елементи ризику природного характеру. На нашу думку, тут формуються регулятивні функції категорії "господарський ризик" у двох формах. О. О. Рудич також виокремлює дві форми (Rudych, 2012):

1. Конструктивна форма полягає в тому, що раціональне $\mathrm{i}$ відповідальне ставлення до ризику відіграє важливу роль своєрідного каталізатора економічної активності, налаштовує суб'єктів господарської діяльності на досягнення вагомих результатів нетрадиційними, ризикованими способами на подолання консерватизму, психологічних бар'єрів, що перешкоджають перспективним новаціям.

2. Деструктивна форма проявляється в ігноруванні ризику. Це механізм ухвалення рішень, які не мають обгрунтування, базуються на аналізі ризику і врахуванні закономірностей розвитку господарської діяльності підприємств.

Аналіз діяльності сільськогосподарських підприємств підтвердив, що зональне виробництво пшениці озимої лише завдяки заходам технологічних процесів неможливе. Необхідні зміни в системі управління, причому не поступові, а кардинальні 3 урахуванням подальшого вдосконалення системи управління на основі компонентів космічного механізму, які підвищать еколого-економічну ефективність сільськогосподарських підприємств.

Водночас космічні чинники у фізичній науці вважають екологічними. Тому в сільському господарстві система управління повинна поєднувати у собі основні 
компоненти космічного механізму, які зумовлюють фази циклів сонячної активності. Ніякі, окремо взяті й загалом, компоненти системи еколого-економічного управління в природокористуванні існувати не можуть без складових космічного механізму, а тільки в сукупності з ними. Це пов'язано з прямою дією сонячної активності на рослини, а також із формуванням атмосферної циркуляції, яка зумовлює створення своїх природних компонентів - температури, вологості, тиску та ін. Тому сільськогосподарське виробництво перебуває під постійним глобальним фізичним впливом фаз циклу сонячної активності. Це потребує виокремити галузями сільського господарства своїх особливостей для виживання у природних умовах з одночасним виробництвом різних видів продукції.

Важливе значення у зазначеному періоді мають складові космічного механізму управління, спрямовані на вирішення проблем, які серйозно загрожують зростанню збалансованості суспільного виробництва. Такі прояви на локальному або регіональному рівні завжди існують і мають подвійну дію: $з$ одного боку, зумовлюють можливості досягнення успіху у виробництві, а 3 іншого - мають місце ризики для невиконання виробничих завдань регіону.
Варто наголосити на точнішій характеристиці важливості екологічних чинників у природокористуванні агроекосистем, де дослідники зазначають, що абсолютно вся сукупність екологічних чинників, які формують природний комплекс, еволюційно зумовлена. Природа конкретно виразилась внаслідок дуже тривалого процесу вдосконалення, оформившись у тонку саморегулювальну систему, пізнавати яку й будувати господарську діяльність відповідно до неї є вагомим завданням (Ваlatckii, et al., 1992).

3 огляду на це, одним із важливих завдань у процесі виробництва сільськогосподарської продукції $\epsilon$ зменшення негативного впливу на НПС і врахування сукупності екологічних чинників, що формують природний комплекс. Зокрема, це стосується площини збалансованого розвитку галузей агроекосистем, які узгоджуються до співіснування з природними компонентами. Це, без сумніву, в майбутньому зніме напруження проблеми зі збалансованості еколого-економічних і соціальних складових у суспільному виробництві та збереженні НПС. Неабияку роль у здійсненні цих завдань відіграє механізм системи еколого-економічного управління у природокористуванні агроекосистем (рисунок).

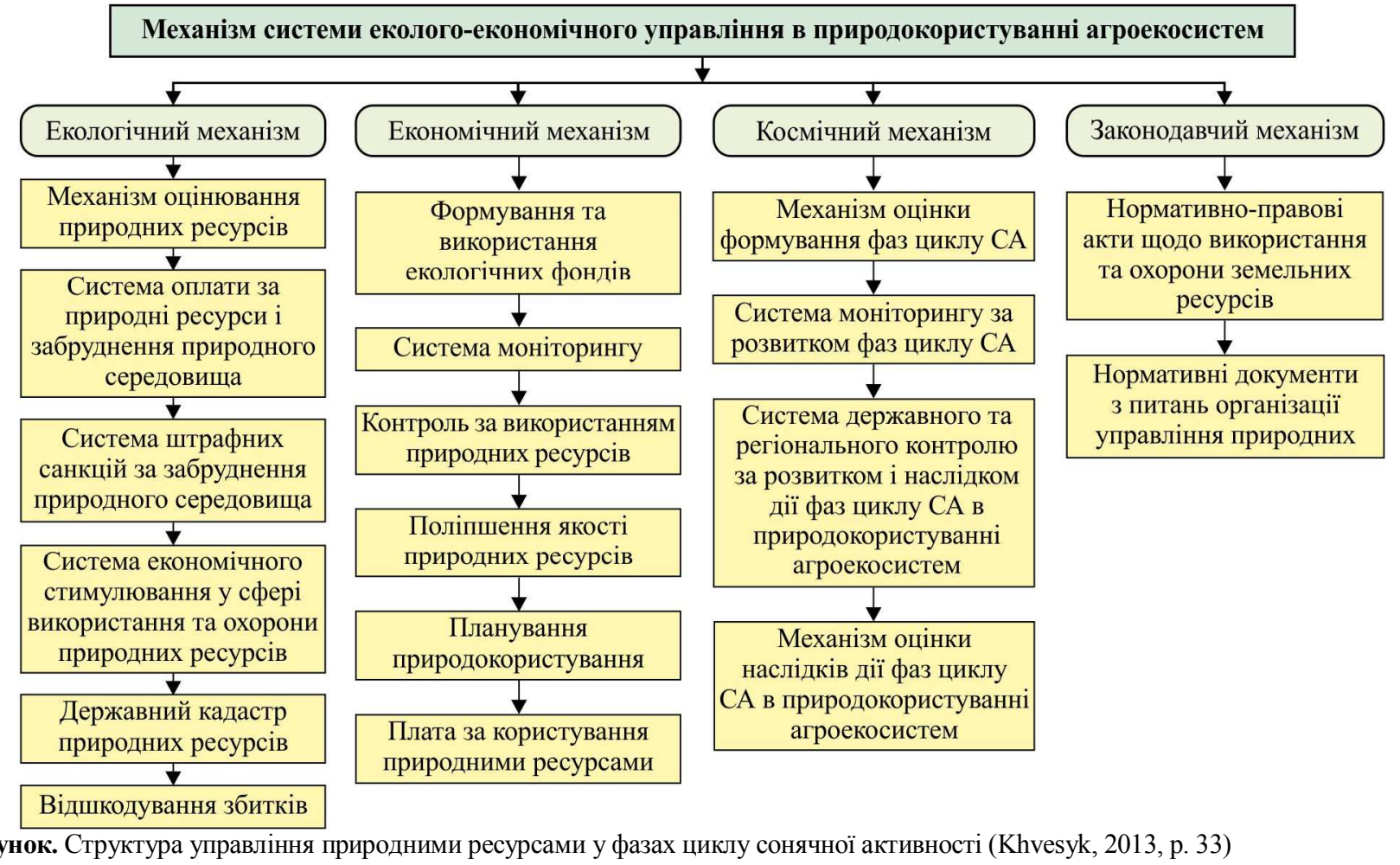

Необхідно зазначити, що збалансованість механізмів в агроекосистемі - складний процес. Адже під час створення сприятливих умов для розвитку збалансованого виробництва в агроекосистемах базовою основою є еколого-економічні, космічні та соціальні складові, які гармонійно між собою пов'язані. Другорядність однієї з них призводить до ще більшої актуалізації проблем у природокористуванні агроекосистем.

Проте В. Н. Зіновчук (Zinovchuk, 2015), досліджуючи проблему збалансованого розвитку, вважає, що збалансований розвиток зазвичай розглядають як певний стан взаємозв'язків екологічної, економічної та соціальної систем, в якому еволюційні цілі цих систем збігаються. Однак у реальності цілі екологічної, еконо-

мічної та соціальної систем не тільки не збігаються, але й суперечать одна одній. Цілі економічної системи спрямовані на збільшення виробництва товарів і послуг. Цілями розвитку соціальної системи є досягнення соціальної справедливості, збереження культури та мов різних народів, підвищення рівня знань людей тощо. Екологічна система має забезпечити збалансованість енергетичних і біологічних процесів. Тому проблема досягнення сталого розвитку полягає насамперед у компромісі щодо суперечливих цілей економічних, екологічних та соціальних систем.

Однак вирішення зазначені проблеми в сільськогосподарському виробництві, безперечно, необхідно. В Україні сільське господарство представляє одну з важ- 
ливих галузей матеріального виробництва. Це зумовлює організацію і проведення комплексу еколого-економічних дій у системі управління. Саме тому останніми роками приділяли належну увагу вирішенню екологічних проблем на основі застосування важелів екологічного механізму. При цьому важливими дійовими важелями екологічного механізму в системі управління можуть бути (Khymynets, 2013; Drebot, et al., 2014):

- екологічне страхування як форма відшкодування збитків, заподіяних порушенням права громадян на безпечне життя та здорове довкілля, яке поширене в багатьох країнах СС;

- екологічна освіта, що охоплює популяризацію екологічної програми національного розвитку, сприяє розробленню i впровадженню інновацій;

- поліпшення інвестиційного клімату в регіоні насамперед завдяки зниженню екологічного ризику;

• удосконалення екологічної інфраструктури виробничої сфери;

- стимулювання системи екологічно орієнтованого підприємництва;

- організація взаємодії державних структур із науково-дослідними організаціями екологічної спрямованості в межах пріоритетних еколого-економічних проектів та ініціатив;

- екологізація процесів споживання і надання послуг, умов формування особистості й трудових ресурсів, типів і видів стандартів;

• екологічна паспортизація регіону.

Одним з індикаторів економічного механізму виявлення постійних соціально-економічних перетворень у суспільному виробництві агроекосистем є моніторинг. На основі системи моніторингу оцінюють потребу та різні сценарії надання послуг, виявляють проблеми у сфері сільськогосподарського виробництва. Моніторинг, як складова економічного механізму, всебічно аналізує на макро- і мікрорівні регіонів виробничу сферу за основними параметрами, що характеризуються великою кількістю найвагоміших показників еколого-економічного спрямування. Особливо це стосується порівняння одержаних виробничих результатів і витрат, економічного ефекту та економічної ефективності в нерозривному зв'язку з раціональним природокористуванням й охороною НПС. Це особливо важливо під час розроблення напрямів відновлення агроекосистем і підтримання якісних властивостей природних ресурсів.

У сучасних умовах розвитку різних галузевих форм виробництва, коли їхні економіки інтегруються в агроекосистемах, неможливо обійтися без економічного механізму, який враховує і контролює економічні чинники. Зокрема це йдеться про ті, що спрямовані на використання природних ресурсів, а також на якісну оцінку відповідності системи управління оцінці впливу окремих інституційних і економічних перетворень на соціальну, економічну та екологічну ефективність його функціонування. Якісні оцінки характеризують повноту й працездатність нових і видозмінених елементів збалансованого ведення суспільного виробництва (Shkilov, et al., 2013).

За визначенням С. В. Мочерного (Zharova, 2006, p. 366), під механізмом розуміють систему, будову, спосіб, які визначають порядок певного виду діяльності або сукупність певних ланок і елементів, що приводять систему (механізм) до дії.

Будь-який механізм, задіяний у суспільному виробництві, що спрямований на збалансований розвиток га- лузей агроекостстем, є сукупністю організацій, інституцій, форм та методів, які використовують для узгодження інтересів суб'єктів господарювання, територіальних громад та органів влади на різних ієрархічних рівнях, забезпечення пропорційного розвитку підсистем у рамках збереження цілісності соціо-еколого-економічної системи (Mishenin, et al., 2013).

Опрацювання літературних джерел у наукових дослідженнях свідчить про часте вживання поняття "економічний механізм". В економічному енциклопедичному словнику за редакцією С. В. Мочерного визначено, що механізм (економічний) - це система прямих та опосередкованих взаємозв'язків між економічним явищем і процесом, передусім між їхніми протилежними сторонами, а також між підсистемами та елементами, які виникають у різних типах економічних систем і між ними (за наявності комплексу умов) (Furdychko, 2014, p. 372).

Природні ресурси, що використовують в агроекосистемах для задоволення потреб людського суспільства (ресурси рослинного і тваринного походження, земельні, водні, рекреаційні тощо), дуже різноманітні, як і можливості їх використання суб'єктами господарювання різної форми власності (Kosterin, 2007). Проте 3 еколого-економічного механізма виокремлюється економічний механізм екологічної політики, де зосереджують увагу на системі сталого розвитку.

"Економічний механізм екологічної політики системи сталого розвитку є дуалістичним за своєю суттю: 3 одного боку, обмежує екологічно несприятливу діяльність господарювання, а 3 другого, - стимулює до діяльності, спрямованої на поліпшення природного середовища" (Budziak, 2013, p. 155).

Соціальні проблеми зазвичай пов'язані з економічними або екологічними. Отже, якщо актуалізуються екологічні чи економічні проблеми, то виникають відповідні й соціальні в природокористуванні агроекосистем. Таке становище доцільно починати виправляти безпосередньо з вирішення еколого-економічних проблем (Derzhavne rehuliuvannia, 2018).

На особливу увагу заслуговують чинники, що формують складну екологічну ситуацію у землекористуванні, які визначив В. М. Будзяк (Derzhavne rehuliuvannia, 2018, p. 219). Зокрема до чинників, які зумовлюють складну екологічну ситуацію, належать: порушення законів природокористування під час обгрунтування моделей споживання і виробництва та розвитку територій; галузевий підхід до системного та інтегрального управління природними ресурсами; недостатне екологічне обгрунтування обсягів використання ресурсів; екологічно не обгрунтована (деформована) структура промислово-виробничого сектора економіка; недотримання у всіх сферах виробничої діяльності природоохоронних вимог та основних принципів сталого природокористування; розселення людей і забудова територій без урахування наявності зсувонебезпечних ділянок, селевих потоків, карсту та ймовірності затоплення територій i значне зменшення лісистості водозборів річок.

Важливим аспектом соціального механізму є створення умов для підвищення рівня та поліпшення якості життя населення у регіонах із розвиненою сферою сільськогосподарського виробництва. При цьому індикаторами вважають: рівень споживання соціальних благ; народжуваність і смертність; фізичне та духовне 
здоров'я населення; тривалість життя тощо. Проте соціально орієнтований регіональний розвиток потребує вирішення нагальних проблем і створення робочих місць та реальних програм зайнятості з урахуванням ідей збалансованості (Drebot, et al., 2014; Derzhavne rehuliuvannia, 2018; Saienko \& Papaika, 2005).

Висновок. Результати наших досліджень свідчать, що в сучасних умовах господарювання для забезпечення збалансованого розвитку сільськогосподарських галузей важливу роль відіграють еколого-економічні, космічні й соціальні механізми. Саме вони в системі еколого-економічного управління сприяють реалізації управлінських рішень щодо функціонування галузей сільськогосподарського виробництва. Передусім це стосується вдосконалення системи управління у межах організаційно-правового поля та вирішення складних соціально-економічних проблем.

Для забезпечення ефективного ведення сільськогосподарського виробництва структура системи екологоекономічного управління має бути доповнена чинниками космічного механізму, які мають велике значення у вирішенні еколого-економічних і соціальних проблем у суспільному виробництві.

3 методичного підходу еколого-економічні та космічні механізми сприяють реалізації стратегічних напрямів господарювання, спрямованих на збереження й ефективне використання природних ресурсів як на рівні окремого суб'єкта господарювання, так і на рівні регіонального утворення. Отже, здійснюється ефективне природокористування, що дає змогу запобігти виникненню негативних процесів та своєчасно вирішити екологічні проблеми в агроекосистемах.

\section{Перелік використаних джерел}

Balatckii, O. F. (Ed.), Melnik, L. G., Kozmenko, S. N., et al. (1992) Ekologo-ekonomicheskie problemy selskokhoziaistvennogo proizvodstva. Kyiv: Urozhai, 144 p. [In Russian].

Budziak, V. M. (2013). Nesilskohospodarske zemlekorystuvannia: problemy ta priorytety. Kyiv: Ahrar Media Hrup, 396 p. [In Ukrainian].

Derzhavne rehuliuvannia. (2018). Retrieved from: http://textbooks.net.ua/content/view/2569/15/. [In Ukrainian].

Drebot, O. I., Shershun, M. Kh., Shkuratov, O. I., \& Furdychko, O. I. (Ed.). (2014). Zbalansovanyi rozvytok lisovoho sektora $v$ konteksti yevropeiskoi intehratsii. Kyiv: Ahrar. nauka, 348 p. [In Ukrainian].
Furdychko, O. I. (2014). Ahroekolohiia. Kyiv: Ahrar. nauka, 400 p. [In Ukrainian].

Furdychko, O. I. (2014). Ekolohichni osnovy zbalansovanoho rozvytku ahrosfery $v$ konteksti yevropeiskoi intehratsii Ukrainy. Kyiv: DIA, 432 p. [In Ukrainian].

Golovina, O. L., \& Melnyk, P. P. (2014). Environmental and economic mechanisms of the land use management in agriculture. Przemyśl Nauka i studia, 18(128), 29-35.

Golovina, O. L., Tereshshenko, V. F., \& Melnyk, P. P. (2015). Environmental and economic mechanisms of ecological audit in the agricultural production. Przemyśl Nauka i studia, 8(139), 27-32.

Khvesyk, M. A. (Ed.). (2013). Formuvannia modeli upravlinnia pryrodnymy resursamy $v$ rynkovykh umovakh hospodariuvannia. Kyiv: DU IEPSR NAN Ukrainy, 304 p. [In Ukrainian].

Khymynets, V. V. (2013). Instytutsiini osnovy ta mekhanizmy zaprovadzhennia staloho rozvytku v Karpatskomu rehioni. (Part 2). Naukovyi visnyk Uzhhorodskoho unyversytetu. Ceriia: Ekonomika, 2(39), 292-298. [In Ukrainian].

Kosterin, V. O. (2007). Ekonomichni mekhanizmy ekolohichnoi polityky u systemi staloho rozvytku. Rehion. ekonomika, 1, 153-160. [In Ukrainian].

Melnyk, P. P. (2016). Ecological and economic regulation mechanism in nature management of agroecosystems. Przemyśl Nauka i studia, 18(149), 16-25.

Mishenin, Ye. V. (Ed.), Kobylianska, I. I., Ustik, T. V., \& Yarova, I. Ye. (2013). Ekolohooriientovane lohistychne upravlinnia vyrobnytstvom. Sumy: Papirus, 248 p. [In Ukrainian].

Rudych, O. O. (2012). Ekonomichna sutnist ryzyku ta osoblyvosti yoho proiavu v diialnosti ahrarnykh pidpryiemstv. Ekonomika ta upravlinnia APK: zb. nauk. pr. Bilotserk. NAU, 7(93), 59-63. [In Ukrainian].

Saienko, H. V., \& Papaika, O. O. (2005). Na shliakhu do staloho rozvytku ekonomiky: hospodarskyi mekhanizm vzaiemodii. Donetsk: Vyd-vo DonDUET im. Tuhan-Baranovskoho, 928 p. [In Ukrainian].

Shkilov, O. V. (Ed.), Ibatullin, M. I., Muzychenko, A. O., et al. (2013). Efektyvnist vykorystannia orendnykh zemel ta zberezhennia yikhnoi rodiuchosti. Kyiv: Chetverta khvylia, 224 p. [In Ukrainian].

Vasylenko, V. O. (Ed.), \& Shmatko, V. H. (2005). Innovatsiinyi menedzhment. (3rd ed.). Kyiv: Tsentr navch. 1-ry, 440 p. [In Ukrainian].

Zharova, L. V. (2006). Mekhanizm obespecheniia ustoichivogo prostranstvennogo razvitiia: sovremennye podkhody. Sovremennye napravleniia teoreticheskikh i prikladnykh issledovanii: sbornik nauch. tr. po materilam. konf. Seriia: Ekonomika, 43-44. [In Russian].

Zinovchuk, N. V. (2015). Zberezhennia bioriznomanittia yak imperatyv zbalansovanoho rozvytku Ukrainy. Zbalansovane pryrodokorystuvannia, 3, 9-12. [In Ukrainian].

П. П. Мельник, Н. В. Курбацка
Институт агроэкологии и природопользования, НААН Украины, г. Киев, Украина

\section{ЭКОЛОГО-ЭКОНОМИЧЕСКИЕ МЕХАНИЗМЫ УПРАВЛЕНИЯ} ПРИРОДОПОЛЬЗОВАНИЕМ В АГРОЭКОСИСТЕМАХ

Рассмотрена важная роль разрабатываемых и использования действующих эколого-экономических механизмов управления в отраслях агроэкосистем, способствующих рациональному использованию и восстановлению природных ресурсов. Проведен анализ действующих механизмов, которые составляют основу гармоничного сочетания принципов для природопользования в агроэкосистемах. Обоснованы особенности действия космического механизма, который представляет собой совокупность состояний и процессов природного происхождения, и по своей масштабности он способен не только вызвать развитие негативных последствий, приводящих к непредвиденным потерям, но и обеспечивать получение в отдельных фазах цикла солнечной активности экономического эффекта от производства сельскохозяйственной культуры. Приведены основные принципы эколого-экономических механизмов управления использованием и охраной земель. Акцентировано внимание на мониторинг как составную экономического механизма, который всесторонне анализирует на макро- и микроуровне регионов производственную сферу важнейшими показателями эколого-экономического направления. На основе проведенных исследований можно сделать вывод, что для обеспечения эффективного ведения сельскохозяйственного производства структура системы эколого-экономического управления должна быть дополнена космическим механизмом, который способствует решению эколого-экономических и социальных проблем в общественном производстве.

Ключевые слова: агроэкосистема; использование; эколого-экономические механизмы; принципы; природопользование; управление. 


\section{ECOLOGICAL AND ECONOMIC MECHANISMS OF NATURAL} RESOURCE MANAGEMENT IN AGROECOSYSTEMS

The article highlights the important role of developing new and operating existing ecological and economic management mechanisms in the fields of agroecosystems that promote rational use and reproduction of natural resources. In the course of the study the authors determined the purpose of the ecological and economic mechanism for natural resource management systems of agroecosystems which forms important tasks of a multilevel economic system. This concerns, in particular, the improvement of the management system in the process of functioning and development of the crops growing economy, solving complex socio-economic problems, and identifying of the dynamic state of the natural environment. Concerning the methodical approach, the ecological and economic mechanism facilitates implementation of strategic directions of management aimed at saving and effective use of natural resource potential both at the level of an individual economic entity and at the level of regional formation. Therefore, an effective nature resource management is implemented, which prevents the occurrence of negative processes and timely solution of environmental problems in agroecosystems. The authors analyzed active mechanisms that provide the basis for harmonious combination of principles for natural resources use in agroecosystems. Furthermore, we substantiated the peculiarities of cosmic mechanism functioning. Any separate components of ecological and economic management in the natural resource management cannot exist without cosmic mechanism components but only together with them. This is due to the direct influence of solar activity on plants as well as the formation of atmospheric circulation which causes the creation of its natural components such as temperature, humidity, pressure, etc. At the same time, agricultural production is under the constant global physical influence of the phases of the solar activity cycle. The components of the cosmic mechanism of management aimed at solving problems which seriously threaten the growth of the social production balance are also of special significance. Such manifestations at the local or regional level always exist and have a dual effect: on the one hand, they determine the possibility of success in production; and on the other hand, there are risks for production tasks not to be fulfilled by economic entities. Thus, we may conclude that for ensuring the effective agricultural management, the structure of ecological and economic management system should be supplemented by the factors of the cosmic mechanism, which determines the solution of ecological and economic and also social problems in social production in order to ensure the effective agricultural management.

Keywords: agroecosystems; use; ecological and economic mechanisms; principles; natural resource management. 